Article

\title{
Biocement Fabrication and Design Application for a Sustainable Urban Area
}

\author{
Chungmin Lee ${ }^{1}$, Hyesun Lee ${ }^{1,2, *}$ and Ok Bin $\operatorname{Kim}^{1,3, *}$ \\ 1 Interdisciplinary Program of EcoCreative, Ewha Womans University, Seoul 03760, Korea; \\ unicorn@ewhain.net \\ 2 Department of Industrial Design, Ewha Womans University, Seoul 03760, Korea \\ 3 Department of Life Science, Ewha Womans University, Seoul 03760, Korea \\ * Correspondence: lhs@ewha.ac.kr (H.L.); kimokbin@ewha.ac.kr (O.B.K.); \\ Tel.: +82-02-3277-3929 (H.L.); +82-02-3277-4133 (O.B.K.)
}

Received: 17 September 2018; Accepted: 2 November 2018; Published: 7 November 2018

\begin{abstract}
Recently, designers have begun to pursue sustainability through the fabrication of materials from living organisms such as bacteria, fungi, and algae in order to address environmental issues. Based on the potential of materials from living organisms, this study has explored a sustainable design application using biocement formed thorough microbially-induced calcite precipitation (MICP), which produces minerals by bacterial metabolic activity. Since most of the studies on MICP thus far have focused on limited fields such as engineering, biotechnology, and geo-technology, this study has focused more on improving the application of biocement in design. We optimized MICP conditions using two parameters (i.e., concentration of urea- $\mathrm{CaCl}_{2}$ and bacterial cell density) through water percolation testing, compressive strength testing, and X-ray diffraction (XRD) analysis. Then, based on the optimized conditions, material compatibility testing and scalability testing were performed, and design application research was conducted as well. As a result, biocement has been identified as a potential sustainable design material, based on its $40 \%$ compressive strength compared to conventional concrete, improved material finish, aesthetic aspects, and environmental impact. This paper contributes to the development of biocement applications in the environmental design field through multidisciplinary research ranging from biological experiments to design applications.
\end{abstract}

Keywords: design for sustainability; biocement; microbially-induced calcite precipitation (MICP); biodesign

\section{Introduction}

We are facing a serious global situation in which natural resources are being depleted, as well as environmental issues such as damage to the planet's biodiversity, with concerns about sustainability continuing to grow. Faced with this global crisis, one of the greatest challenges of this century is changing our infrastructure to be environmentally sustainable.

Driven by environmental responsibility, designers have begun to recognize environmental issues, leading them to reprioritize their goals and change their materials for a more resilient and sustainable future $[1,2]$. One innovative approach for improving sustainability is the convergence of design and biology [3,4]. Designers are beginning to use living organisms such as bacteria, algae, and fungi to fabricate sustainable materials and manufacturing methods with reduced environmental impact. This interdisciplinary research between biology and design has already been applied in a variety of areas, from manufacturing to architecture, in order to overcome the environmental crisis in the design field $[3,5]$. 
Concrete is one of the main materials used in the construction industry because of its relatively low cost and high strength [6]. This industry is growing worldwide at $0.8-1.2 \%$ per year, and consumption is expected to increase to 3.7-4.4 billion tons in 2050 [7].

However, concrete consumes high energy and is an environmentally unfriendly material that negatively impacts the environment at all stages of its manufacturing process [8]. The cement industry, which accounts for the major composite of concrete, is one of the largest producers of carbon dioxide $\left(\mathrm{CO}_{2}\right)$, contributing to $10 \%$ of global $\mathrm{CO}_{2}$ emissions from the manufacturing process requiring the burning of fossil fuels to generate extremely high temperatures $\left(1500^{\circ} \mathrm{C}\right)$ as well as the chemical process for cement creation decomposing calcium carbonate into calcium oxide and $\mathrm{CO}_{2}$ [6]. Additionally, cement's main ingredients need to be produced and mined on a massive scale and transported considerable distances, increasing energy consumption, greenhouse gas emissions, and landscape mutilation [9]. Considering all stages of its production cycle from mining to final disposal, cement is not a sustainable material and greatly affects the environment.

With this concern for the environmental impact from cement manufacturing, microbially-induced calcite precipitation (MICP) is currently being explored extensively as a bio-based technique in multidisciplinary fields such as geotechnical and material engineering, as well as in environmental applications [8,10-12]. However, there are still some challenges toward application of MICP in practice [13].

MICP is one of the biomineralization processes that can produce minerals via various metabolic activities by almost all kinds of bacteria, with the hydrolysis of urea by ureolytic bacteria being one of the most popular and easily controlled reactions used to precipitate minerals in a short period of time $[14,15]$.

Sporosarcina pasteurii (formerly Bacillus pasteurii), which is a gram-positive, aerobic, and ureolytic bacterial species, is used in this study due to its unique features: non-pathogenicity, high stability, higher urease activity than other urease bacteria, and ability to tolerate high alkaline conditions over $\mathrm{pH} 8.5[12,16,17]$. In the MICP process, S. pasteurii plays a major role in creating a high alkaline environment through urease activity, and may serve as a nucleation site for $\mathrm{CaCO}_{3}$ precipitation on its surface [11]. By this process occurring in the pores of unbounded sand, the sand particles adhere together with calcium carbonate. This cementitious material is called "biocement" and is used as an alternative sustainable material, since it is produced by a biological process that does not involve burning fuels or using harmful chemical processes [9].

Enzyme urease is produced by $S$. pasteurii and catalyzes the hydrolysis of urea into ammonia $\left(\mathrm{NH}_{3}\right)$ and carbonic acid $\left(\mathrm{H}_{2} \mathrm{CO}_{3}\right)$, as shown in Equations (1) and (2). $\mathrm{NH}_{3}$ and $\mathrm{H}_{2} \mathrm{CO}_{3}$ are converted into ammonium $\left(\mathrm{NH}_{4}^{+}\right)$, bicarbonate ions $\left(\mathrm{HCO}_{3}^{-}\right)$, and hydroxide ions $\left(\mathrm{OH}^{-}\right)$by reaction with water, as shown in Equations (3) and (4). The production of hydroxide ions $\left(\mathrm{OH}^{-}\right)$increases the $\mathrm{pH}$ value in the surrounding area (4). As $\mathrm{pH}$ increases, bicarbonate ions $\left(\mathrm{HCO}_{3}{ }^{-}\right)$are converted into carbonate ions $\left(\mathrm{CO}_{3}{ }^{2-}\right)(5)$, which makes bacterial cell surfaces more negative and attracts positively charged calcium ions $\left(\mathrm{Ca}^{2+}\right)$ from the environment to deposit onto the cell surface $(6)[12,14,18,19]$.

$$
\begin{gathered}
\mathrm{CO}\left(\mathrm{NH}_{2}\right)_{2}+\mathrm{H}_{2} \mathrm{O} \stackrel{\text { urease }}{\longrightarrow} \mathrm{NH}_{2} \mathrm{COOH}+\mathrm{NH}_{3} \\
\mathrm{NH}_{2} \mathrm{COOH}+\mathrm{H}_{2} \mathrm{O} \rightarrow \mathrm{NH}_{3}+\mathrm{H}_{2} \mathrm{CO}_{3} \\
\mathrm{H}_{2} \mathrm{CO}_{3} \leftrightarrow \mathrm{HCO}_{3-}+\mathrm{H}^{+} \\
2 \mathrm{NH}_{3}+2 \mathrm{H}_{2} \mathrm{O} \leftrightarrow 2 \mathrm{NH}_{4-}+2 \mathrm{OH}^{-} \\
\mathrm{HCO}_{3-}+\mathrm{H}^{+}+2 \mathrm{OH}^{-} \leftrightarrow \mathrm{CO}_{3}^{2-}+2 \mathrm{H}_{2} \mathrm{O} \\
\mathrm{Ca}^{2+}+\mathrm{Cell}_{4} \leftrightarrow \mathrm{Cell}-\mathrm{Ca}^{2+} \\
\mathrm{Ca}^{2+}+\mathrm{CO}_{3}^{2-} \leftrightarrow \mathrm{CaCO}_{3}
\end{gathered}
$$


Bacteria may play a major role in creating a high alkaline environment through metabolic activities, and serve as nucleation sites for $\mathrm{CaCO}_{3}$ precipitation on their surfaces [20]. During this process, calcium carbonate is usually precipitated into three polymorphic forms, the order of their usual stability being calcite, aragonite, and vaterite [11].

The potential benefits of biocement have led designers to begin to apply it to their work [21,22]. However, since MICP is a complex chemical mechanism with many environmental influences [23-25], the complexity of the MICP procedure creates barriers for applying biocement in the design field. Furthermore, most of the studies on MICP thus far have generally focused on narrow fields, such as geo-technology, due to engineering barriers. Therefore this research has focused on the applicability of biocement in the design for sustainability as follows:

(1) Study of MICP to improve the strength of biocement through water permeability analysis and compressive strength testing.

(2) Aesthetic and scalability study using biocement.

(3) Design of an eco-friendly building module using biocement.

We have explored biocement applications by considering ecological aspects. Biocement was applied as a mediator between two issues: decreasing wild bee populations due to habitat loss and continued expansion of urbanization [26].

Pollinators, especially wild bees, play a vital role in the reproduction of many plant species in the planet's ecosystems [27]. However, they are currently under threat, mainly due to urbanization causing the decline of nest density of wild bees through the loss of ecological features in cities. The surfaces of urbanized buildings are usually made of solid concrete where wild bees cannot build nests [26]. This is fatal to wild bees because they build individual nests in small tunnels or holes of dead wood, ground, and sandy banks for their larvae.

Urban areas will continue to expand and become more diverse, meaning that pollinators will continue to come into contact with urbanization-even more so than now [28]. Many studies have found that urban habitats can contain abundantly high pollinator richness and have demonstrated positive effects on wild bees [29]. If we invite pollinators into our buildings and cities, each building can both create conditions conducive to our life and simultaneously provide pollination services and opportunities for ecosystems [30,31].

In this study, we applied biocement as a building skin to pursue urban biodiversity by securing the habitat of wild bees. This study has obtained biocement with $40 \%$ strength of conventional concrete and has high water impermeability, and it is expected that biocement can be applied in environmentally friendly exterior materials. The concept of this design work is to achieve sustainability through interdisciplinary research in ecology, design, and biology. This study contributes to the expansion of biocement applications and shows the potential convergence between design, biology, and ecosystem engineering for sustainable environment initiatives.

\section{Material and Methods}

\subsection{Strain and Cultivation}

Sporosarcina pasteurii KCTC 3558 was shipped in a freeze-dried state from Korean Collection of Type Cultures (KCTC). The main culture was inoculated 1\% from subculture, and was aerobically grown in $100 \mathrm{~mL} \mathrm{NH}_{4}$-YE liquid medium (ATCC 1376) on a shaking incubator (N-BIOTEK, South Korea) with $150 \mathrm{rpm}$ at $30^{\circ} \mathrm{C}$ for $9-10 \mathrm{~h}$ to the late exponential phase $\left(\mathrm{OD}_{600} 2.5\right)$. The $\mathrm{NH}_{4}-\mathrm{YE}$ medium (ATCC 1376) contained yeast extract $20 \mathrm{~g} / \mathrm{L},\left(\mathrm{NH}_{4}\right)_{2} \mathrm{SO}_{4} 10 \mathrm{~g} / \mathrm{L}$, and $0.13 \mathrm{M}$ Tris buffer ( $\mathrm{pH}$ 9.0) [32]. The culture was cooled and stored at $4{ }^{\circ} \mathrm{C}$ before being used for MICP. 


\subsection{Sand Characteristics}

The sand from Jumunjin beach located at Gangneung, South Korea (grain size of 250 to $500 \mu \mathrm{m}$ ) was used for MICP [33]. In addition, waste marble powder and color sand were used for biocement compatibility tests. The waste marble powder $(<300 \mu \mathrm{m})$ was obtained from the Marble Sculpture workshop at the Department of Sculpture of Ewha Womans University in Seoul, South Korea. Color sand (250-400 $\mu \mathrm{m}$; Uniart Korea, South Korea) was used as a color source.

\subsection{Urease Activity Test}

Sporosarcina pasteurii and two reference strains of Escherichia coli and Actinobacillus succinogenes were aerobically cultivated overnight in a $5 \mathrm{~mL}$ BHI medium [12] at $150 \mathrm{rpm}$ and $30^{\circ} \mathrm{C}$. Then, $1 \mathrm{~mL}$ of $10 \mathrm{~g} / \mathrm{L}$ urea was added to each culture, with cultures then being further cultivated for $10 \mathrm{~h}$. The $\mathrm{pH}$ change by urease activity was measured by Litmus paper.

\subsection{MICP (Microbially Induced Calcite Precipitation)}

Solutions. For MICP, $8 \mathrm{~mL}$ cementation solution, $10 \mathrm{~mL}$ bacterial culture, and $10 \mathrm{~mL}$ fixative solution were added to the $15 \mathrm{~g}$ sand. The sand was contained in a $10 \mathrm{~mL}$ plastic syringe, and the solutions were added to the top surface containing sand (Figure 1). Three various cementation solutions were prepared, in which the concentrations of urea $(0.12 \mathrm{M}, 0.4 \mathrm{M}$, or $1.5 \mathrm{M})$ and $\mathrm{CaCl}_{2}$ $(0.055 \mathrm{M}, 0.2 \mathrm{M}$, or $0.75 \mathrm{M})$ were varied. In addition, the solution contained $25 \mathrm{mM} \mathrm{NaHCO}_{3}, 150 \mathrm{mM}$ $\mathrm{NH}_{4} \mathrm{Cl}$, and $7.5 \mathrm{~g} / \mathrm{L}$ brain heart infusion (BHI; Merck, Darmstadt, Germany), and was set to $\mathrm{pH} 7$ (Table 1) $[15,21,34]$. Two densities (1X, 10X) of bacterial solution were prepared, for which 1X refers to the bacterial culture and 10X refers to the 10-fold concentrated bacterial resuspension in $\mathrm{NH}_{4}-\mathrm{YE}$ medium. The fixative solution was $55 \mathrm{mM} \mathrm{CaCl}_{2}$ [21] (Table 1).

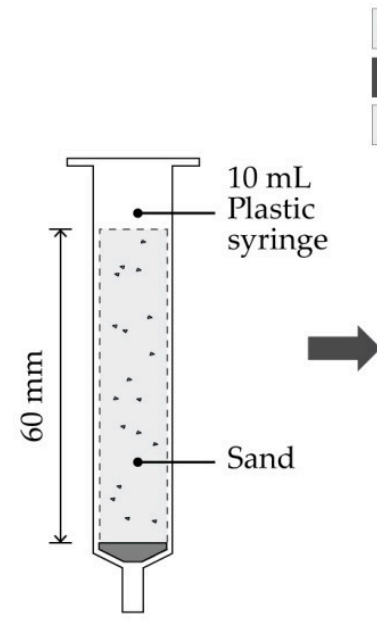

(a)

\section{Cementation solution \\ Bacterial solution}

Fixation solution

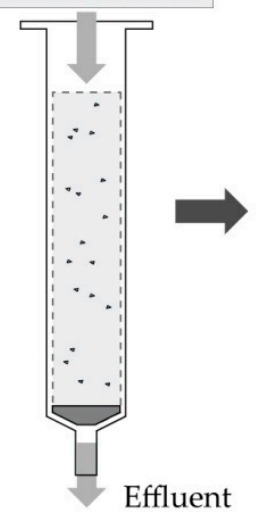

(b)

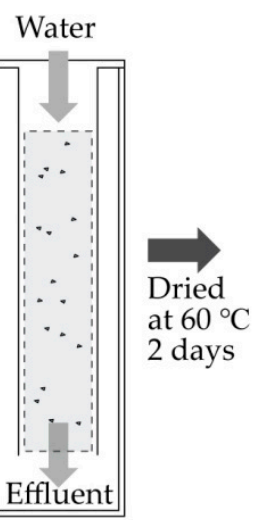

(c)

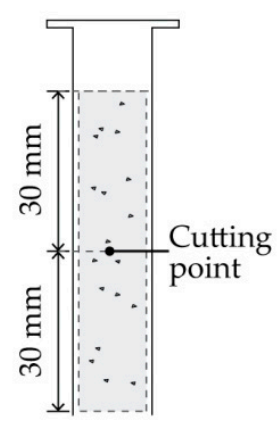

(d)

Figure 1. Experimental setup to test two factors affecting microbially-induced calcite precipitation (MICP): concentration of cementation solution, bacterial density. (a) A plastic syringe (10 mL) was prepared as a mold and the syringe was filled with sand A to $60 \mathrm{~mm}$ height. (b) Bacterial solution, fixation solution $\left(\mathrm{CaCl}_{2}\right.$ aqueous solution), and cementation solution were sequentially injected into the top surface of the syringe. (c) Experimental setup for water absorption test. (d) Cutting the sample in three parts to identify the hardness. 
Table 1. Summary of sand and solutions for MICP.

\begin{tabular}{|c|c|c|c|}
\hline & Control Variable & Range & References \\
\hline \multirow{2}{*}{ Sand type } & Grain size & $250-500 \mu \mathrm{m}$ & [33] \\
\hline & Sterilization & Non sterilization & This study \\
\hline \multirow{3}{*}{ Bacterial solution } & Microorganism & Sporosarcina pasteurii & [12] \\
\hline & Bacterial density & $\mathrm{OD}_{600} 2.4-2.7$ & [35] \\
\hline & Carbon source & Yeast extract & [15] \\
\hline \multirow{5}{*}{ Cementation solution } & Calcium source & $\mathrm{CaCl}_{2}$ & [36] \\
\hline & Nitrogen source & Urea & [37] \\
\hline & Added substances & $25 \mathrm{mM} \mathrm{NaHCO}_{3}$ & [15] \\
\hline & $\mathrm{pH}$ & $\begin{array}{c}150 \mathrm{M} \\
7.0\end{array}$ & [15] \\
\hline & Sterilization & Non-sterilization & This study \\
\hline Fixation solution & $\begin{array}{l}\text { Attaching bacteria to } \\
\text { sand particles }\end{array}$ & $55 \mathrm{mM} \mathrm{CaCl}_{2}$ & [21] \\
\hline
\end{tabular}

Module and process for MICP. The biocement mold was fabricated with a non-porous, non-reactive PVC (polyvinyl chloride) cylinder pipe $(0.3 \mathrm{~mm}$ in thickness, $30 \mathrm{~mm}$ in diameter, and $60 \mathrm{~mm}$ in height) (Figure 2). The bottom of the mold was covered by a perforated steel plate ( $0.5 \mathrm{~mm}$ in thickness) with a $0.5 \mathrm{~mm}$ diameter for effluent. The sand was poured into the PVC pipe at a height of $10 \mathrm{~mm}$, then $10 \mathrm{~mL}$ of bacterial solution $\left(\mathrm{OD}_{600} 2.5\right)$ was added on top of the sand and mixed for a homogeneous bacterial distribution (Figure 2) [38]. Then, $10 \mathrm{~mL}$ of fixation solution was poured onto the top of the sand and mixed with the sand. The above procedure was repeated every $10 \mathrm{~mm}$ of height in order to make a $60 \mathrm{~mm}$ high sand column. When the sand reached $60 \mathrm{~mm}, 10 \mathrm{~mL}$ of cementation solution was added on top, where it was allowed to drain out (Figure 2). Then, the mold was covered with a perforated plate and rotated 180 degrees from the top to the bottom. The $10 \mathrm{~mL}$ of cementation solution was poured onto the top one final time. The cementation solution was applied twice a day for 20 days to the point that it could not pass through the coagulated surface. After 20 days, the biocement sample was rinsed with distilled water twice and dried at $60^{\circ} \mathrm{C}$ (Table 2).

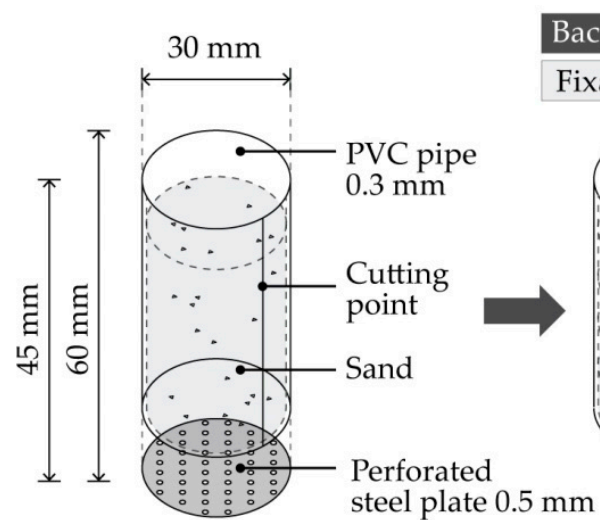

(a)

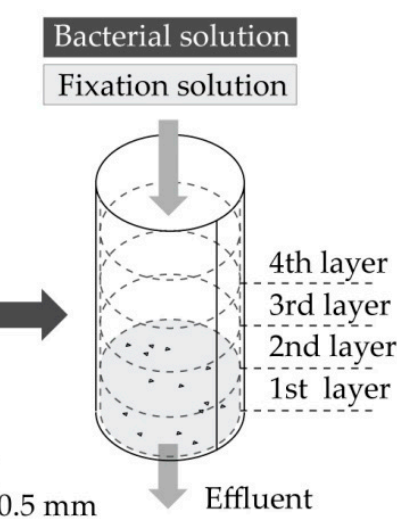

(b)

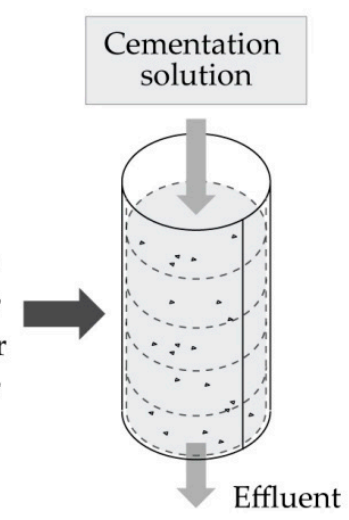

(c)

Figure 2. Experimental setup for MICP: (a) A PVC pipe was prepared as a mold and a perforated steel plate was used for drainage. (b) Injection of bacterial solution and fixation solution alternatively on each sand layer. This process is repeated once again after the mold is inverted. (c) The cementation solution was injected into the top surface. 
Table 2. Summary of treatment procedure.

\begin{tabular}{|c|c|c|c|}
\hline & Control Variable & Range & References \\
\hline Mold & Material & $\begin{array}{l}\text { PVC cylinder pipe } \\
\text { (0.3 mm in thickness, } \\
30 \mathrm{~mm} \text { in diameter, } \\
\text { and } 60 \mathrm{~mm} \text { in height), } \\
\text { Perforated steel plate } \\
\text { (0.5 mm in thickness, } \\
0.5 \mathrm{~mm} \text { in hole diameter })\end{array}$ & This study \\
\hline $\begin{array}{l}\text { Bacterial culture } \\
\text { Injection }\end{array}$ & Bacterial placement & Layer by layer ${ }^{1}$ & [38] \\
\hline \multirow{6}{*}{$\begin{array}{l}\text { Cementation solution } \\
\text { Injection }\end{array}$} & Injection frequency & 2 times a day & \multirow{6}{*}{ This study } \\
\hline & Injection time (days) & $14-21$ & \\
\hline & Injection strategy & $\begin{array}{l}\text { Applied from the top to } \\
\text { the bottom by gravity }\end{array}$ & \\
\hline & Percolation & Percolated by gravity & \\
\hline & Temperature $\left({ }^{\circ} \mathrm{C}\right)$ & $25-30^{2}$ & \\
\hline & $\begin{array}{l}\text { Total injection solution } \\
\text { per each sample }(\mathrm{mL})\end{array}$ & 200 & \\
\hline
\end{tabular}

Note: ${ }^{1}$ Alternating bacterial culture and fixation solution for even distribution of urease activity; ${ }^{2}$ The optimum temperature for $S$. pasteurii is $30^{\circ} \mathrm{C}$ under field conditions.

\subsection{Evaluation of Biocement}

\subsubsection{Water Percolation and Sand Loss}

Water was poured into the pipe until the top edge of the biocement mold was filled. The amount of water that passed through the biocement sample for five minutes was measured. All samples were dried at $60^{\circ} \mathrm{C}$, and the biocement sample was weighed in order to compare the weight before and after water penetration. Then the samples were cut at the $30 \mathrm{~mm}$ height to confirm the internal durability of the biocement (Figure 2).

\subsubsection{X-ray Diffraction (XRD) Analysis}

The biocement sample was divided into three equal portions ( $15 \mathrm{~mm}$ in height) with a jeweler saw, and each section was observed through a digital microscope (DISMIS-M, Siwon Optical Technology, Anyang, Korea) before being ground for XRD analysis.

X-ray diffraction analysis was conducted with a diffractometer (Rigaku D/Max-2000/PC, Rigaku, Tokyo, Japan) with Ni-filtered $\mathrm{Cu} \mathrm{K} \alpha$ radiation. The wavelength of $\mathrm{Cu} \mathrm{K} \alpha$ X-rays was $1.5418 \AA$. Three parts of the sample were ground separately in a mortar until all of the sand particles were finely ground. Two equal amounts of ground sand were taken from each section for accurate XRD analysis. X-ray diffraction irradiation was performed according to the position of the sample.

\subsubsection{Compressive Strength Test}

All surfaces of the biocement samples were made flat for the sake of accuracy. The elastic modulus $\left(\mathrm{N} / \mathrm{m}^{2}\right)$ of the sample was measured, which is a measure of the resistance to elastic deformation when the load is applied and compared with high-strength concrete. This compressive strength test was measured under the upper limit (the area within $0.2 \%$ compressive displacement of the initial specimen). The sample was placed into the machine vertically. A load cell (which converts force into a measurable electrical output) and a displacement sensor (which measures compressive displacement) were used measurements conducted in the compressive strength test. While the preload ( $340 \mathrm{~N})$ was applied to the sample, an additional $200 \mathrm{~N}$ load was applied ten times in order to obtain an average compressive strength. 


\subsection{Material Studies of Compatibility and Scalability Using the Biocement}

Microbially-induced calcite precipitation in this study was performed by repetitive steps of mixing $10 \mathrm{~mm}$ sand and solutions up to $60 \mathrm{~mm}$ in height. During these steps, a small amount of color sand and waste marble powder were inserted into the middle of layers (Figure 3). The cementation solution $\left(0.75 \mathrm{M} \mathrm{CaCl}_{2}\right.$ and $1.5 \mathrm{M}$ urea) was then used. For scalability testing, mold B (diameter $60 \mathrm{~mm}$ ) was prepared in the same way with $120 \mathrm{~mm}$ in height with main sand, color sand, and waste marble powder (Figure 3).

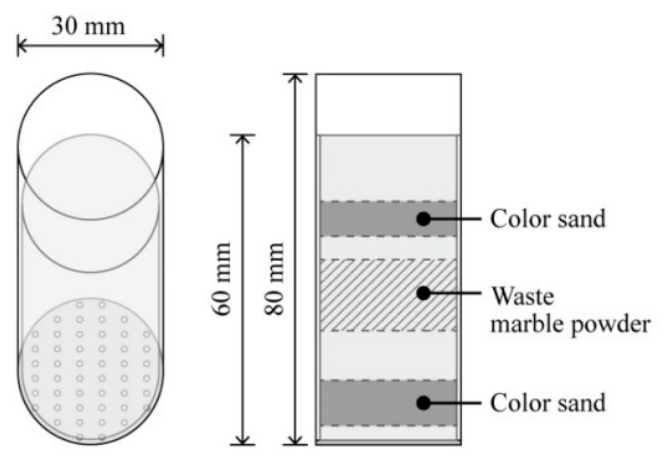

Figure 3. Different layer composition plan.

\subsection{Design Application Using Biocement}

The PVC film (0.5 mm in thickness), a non-porous and non-reactive material, was formed in a hexahedral shape in half the size $(85 \mathrm{~mm} \times 45 \mathrm{~mm} \times 28 \mathrm{~mm})$ of the conventional brick size $(190 \mathrm{~mm}$ $\times 90 \mathrm{~mm} \times 57 \mathrm{~mm}$ ). At the bottom of a hexahedron, perforated steel plates were attached for drainage (Figure 4). After the PVC mold was cut vertically on one surface, it was fixed with tape. The straw was then attached $10 \mathrm{~mm}$ above the bottom of the mold. Next, the mold was filled with the main sand, and bacterial culture and fixative solution were alternately poured. This work was performed every $10 \mathrm{~mm}$ in height and repeatedly performed until the sand accumulated up to $90 \mathrm{~mm}$ in height. Non-porous material straw $(3 \mathrm{~mm})$ was used as a mold for various sizes of holes. The ends of the holes were then blocked (Figure 4). Finally, the cementation solution $\left(0.75 \mathrm{M} \mathrm{CaCl}_{2}, 1.5 \mathrm{M}\right.$ urea) was applied for 14 days and block modules were dried at $60^{\circ} \mathrm{C}$.

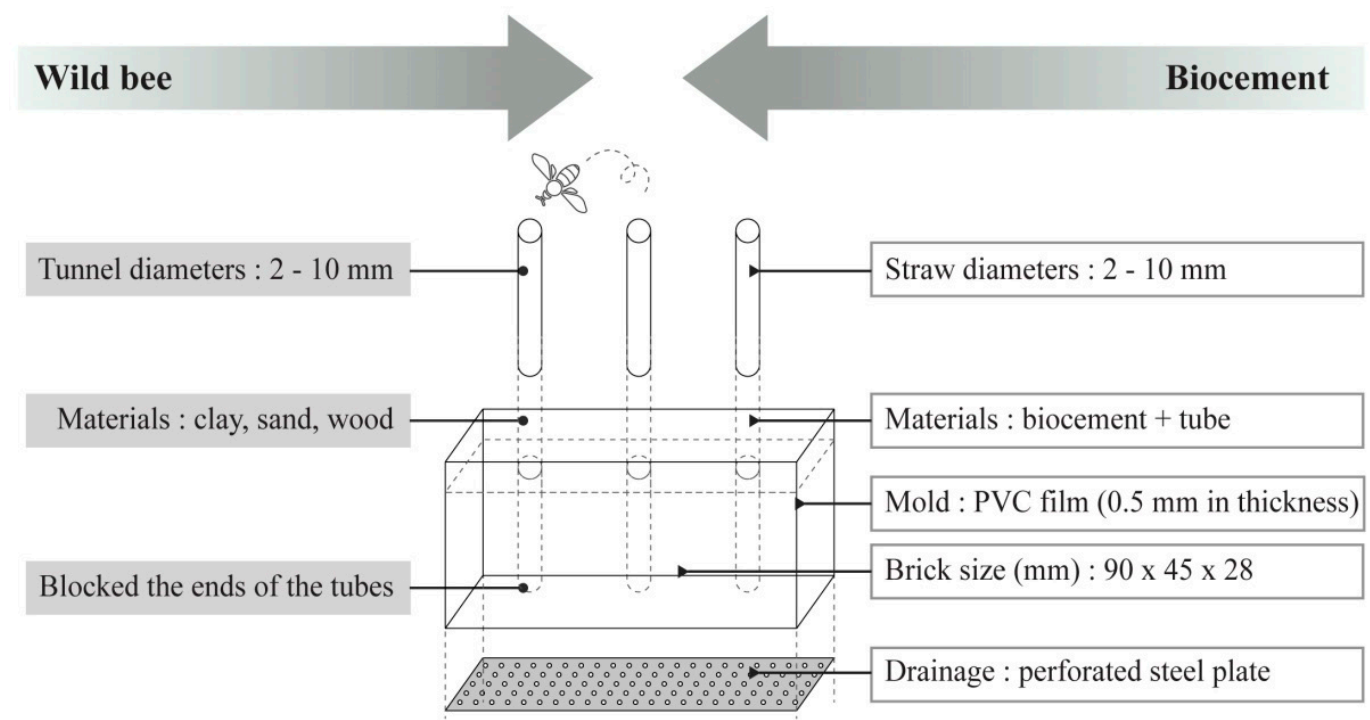

Figure 4. Mold design considering wild bees; a 0.5-mm thick PVC film was formed in a hexahedral shape as a mold. 


\section{Results and Discussion}

The need for proper laboratory conditions combined with the rigorous procedures of MICP can be a huge barrier to the application of MICP in multidisciplinary fields; therefore, all experiments except for bacterial cultivation were conducted under non-sterilized conditions.

\subsection{Study of MICP}

\subsubsection{Cultivation of S. pasteurii for MICP}

The Sporosarcina pasteurii was aerobically cultivated in medium $\mathrm{NH}_{4}$-YE (ATCC 1376). The growth showed the exponential phase from 3 to $10 \mathrm{~h}$ (Figure S1). To produce the largest amount of biocement, the bacterial culture from the late exponential phase at 9 to $10 \mathrm{~h}\left(\mathrm{OD}_{600}\right.$ around 2.5 to 2.7$)$ was used to precipitate calcium carbonate crystals (biocement) in the sand.

Microbially-induced calcite precipitation is absolutely dependent on the urease activity of S. pasteurii, which increases the surrounding $\mathrm{pH}$. The urease activity of $S$. pasteurii was confirmed by $\mathrm{pH}$ change caused by urea degradation (Figure S2). After the addition of $0.15 \mathrm{M}$ urea, the $\mathrm{pH}$ value of S. pasteurii culture increased to $\mathrm{pH} 12$, while the $\mathrm{pH}$ values of cultures of Escherichia coli and Actinobacillus succinogenes were maintained at $\mathrm{pH} 6$.

\subsubsection{Study of Bacterial Solution}

The difference in the two densities (1X,10X) of bacterial solution did not significantly affect the MICP efficiency according to the results of the water percolation test and the loss of sand weight (Table 3). The concentrations of cementation solution had a more significant effect on the MICP results, and the cell density led to very slight differences in MICP efficiency depending on the concentration of the cementation solution (A-C). Overall, the combination of $1 \mathrm{X}$ cell density and the highest concentration of cementation solution $\left(1.5 \mathrm{M}\right.$ urea and $\left.0.75 \mathrm{M} \mathrm{CaCl}_{2}\right)$ in $\mathrm{C} 1$ produced the biocement sample with the highest water impermeability, lowest sand loss (Table 3), and highest durability (Figure 5).

Table 3. The concentration of urea- $\mathrm{CaCl}_{2}$ and cell density influenced the efficiency of MICP. The largest amount of biocement sample was formed and the high water impermeability was observed in $\mathrm{C}$ with the highest concentration of urea- $\mathrm{CaCl}_{2}$. Additionally, the least amount of bio-cement was lost after water permeated it.

\begin{tabular}{|c|c|c|c|c|c|c|c|c|}
\hline \multicolumn{2}{|c|}{ Name } & \multirow{3}{*}{$\begin{array}{c}\text { [Urea] } \\
\text { (M) } \\
0.12\end{array}$} & \multirow{3}{*}{$\begin{array}{c}{\left[\begin{array}{c}\left.\mathrm{CaCl}_{2}\right] \\
(\mathbf{M})\end{array}\right.} \\
0.055\end{array}$} & \multirow{3}{*}{$\begin{array}{c}\begin{array}{c}\text { Cell } \\
\text { Density } \\
\text { (time) }\end{array} \\
1 \\
10\end{array}$} & \multirow{3}{*}{$\begin{array}{c}\begin{array}{c}\text { Biocement } \\
\text { Sample } \\
\text { Weight (g) }\end{array} \\
19.3 \\
17.7\end{array}$} & \multirow{3}{*}{$\begin{array}{c}\begin{array}{c}\text { Water } \\
\text { Percolation }\end{array} \\
\text { Quantity (mL) } \\
51 \\
32.5\end{array}$} & \multirow{3}{*}{$\begin{array}{c}\begin{array}{c}\text { Biocement Sample } \\
\text { Weight (g) after Water } \\
\text { Percolation Test }\end{array} \\
14.1 \\
16.3\end{array}$} & \multirow{3}{*}{$\begin{array}{c}\begin{array}{c}\text { Loss of Sand } \\
\text { Weight (g) }\end{array} \\
5.18 \\
1.42\end{array}$} \\
\hline \multirow{2}{*}{ A } & $\mathrm{A} 1{ }^{1}$ & & & & & & & \\
\hline & A2 & & & & & & & \\
\hline \multirow{2}{*}{ B } & B1 & \multirow{2}{*}{0.4} & \multirow{2}{*}{0.2} & 1 & 21.4 & 6.2 & 20.3 & 1.06 \\
\hline & B2 & & & 10 & 24.5 & 10 & 24.1 & 0.4 \\
\hline C & $\mathrm{C} 2$ & 1.5 & 0.75 & 10 & 25 & 0 & 25 & 0 \\
\hline
\end{tabular}

Note: The cell density and urea- $\mathrm{CaCl}_{2}$ concentration of ${ }^{1}$ are used in References [21,39], and those of ${ }^{2}$ are used in References [8,40,41]. 


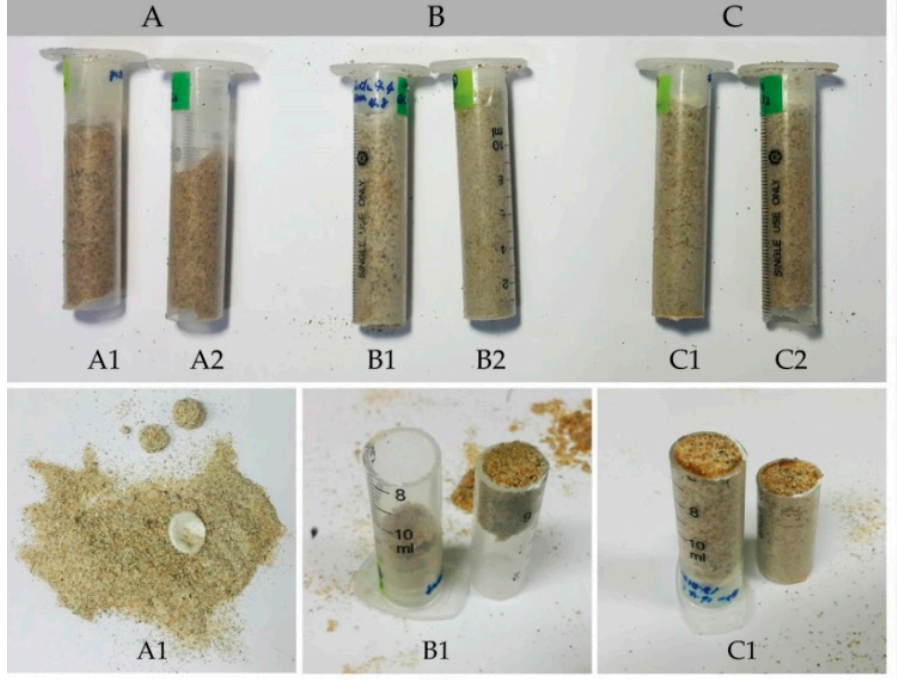

(a)

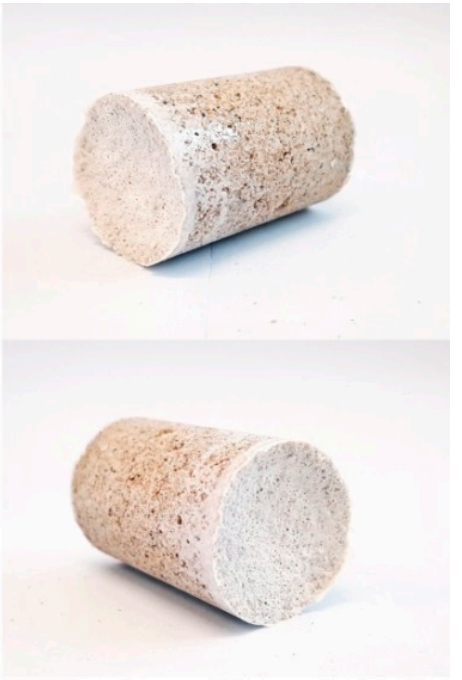

(b)

Figure 5. The result for the MICP optimization condition: (a) The degree of sand hardness differed depending on the concentration of cementation solution (urea-CaCl $\mathrm{C}_{2}$ ). $\mathrm{C} 1$ showed a high degree of hardness from the top to the bottom. (b) Biocement sample made under optimized conditions.

\subsubsection{Study of Cementation Solution}

Table 3 and Figure 5 show that the highest concentrations of urea $(1.5 \mathrm{M})$ and $\mathrm{CaCl}_{2}(0.75 \mathrm{M})$ produced the highest MICP efficiency among the three concentrations $(\mathrm{A}-\mathrm{C})$. It was observed that $\mathrm{C}$ samples with the highest concentrations of urea $(1.5 \mathrm{M})$ and $\mathrm{CaCl}_{2}(0.75 \mathrm{M})$ had much higher water resistances than the B and A samples, had only slight sand loss (Table 3), and showed significantly higher durability at the section cutting (Figure 5).

In contrast, the A samples with the lowest concentration of urea $(0.12 \mathrm{M})$ and $\mathrm{CaCl}_{2}(0.055 \mathrm{M})$ had a large amount of sand loss with weak water resistance (Table 3 ), resulting in only a small amount of mass remaining on the top (Figure 5).

Another important factor for cementation solution was the addition of $25 \mathrm{mM} \mathrm{NaHCO}_{3}, 150 \mathrm{mM}$ $\mathrm{NH}_{4} \mathrm{Cl}$, and $7.5 \mathrm{~g} / \mathrm{L}$ BHI. Compared with the sample treated with the cementation solution containing $\mathrm{NaHCO}_{3}$ and $\mathrm{NH}_{4} \mathrm{Cl}$, the sample with the cementation solution containing only urea and $\mathrm{CaCl}_{2}$ did not show any MICP activity.

\subsubsection{Study of the Cementation Process}

The most optimized method of injecting the bacterial solution, fixation solution, and cementation solution was as follows: $10 \mathrm{~mL}$ of the bacterial solution was poured into $10 \mathrm{~g}$ of sand, followed by the injection of $10 \mathrm{~mL}$ of the fixation solution and mixing with sand. The sand, bacterial solution, and fixation solution were alternatively stacked, and this process was repeatedly performed in order to fill the mold to the planned height. By alternately injecting bacterial solution and fixation solution into each layer of sand, the bacteria were evenly distributed and fixed in the sand with a curved shape and edge of the mold.

When the bacterial solution and the cement solution were mixed together before being injected into the sand, the biocement was concentrated on the surface of the sample resulting in a weak strength of the sample. In addition, when the bacterial solution and fixation solution were injected into the sand without dividing the sand layer, the bottom of the sample was not hardened.

\subsubsection{Study of Mold}

Material. The material of the mold was made of PVC film $(0.3 \mathrm{~mm}-0.5 \mathrm{~mm}$ in thickness $)$ and the drainage part was made of perforated plate ( $0.5 \mathrm{~mm}$ in thickness) with a diameter of $500 \mu \mathrm{m}$. 
The perforated plate showed little adhesion with the biocement sample, indicating that it is necessary to study other drainage materials. The material of the module was additionally investigated with 3D printer filament PLA (polylactic acid), concrete, syringe, and wooden material. The 3D filament PLA material, concrete, and syringe showed adhesion with the biocement sample such that the biocement sample could not be separated from the mold; the wood had issues with absorption.

Structure. The mold generated the most optimized biocement sample in the form of the vertical column structure. The transformation of the mold was applied to the plane. To produce uniformity and repetitive production of the modules, each module was assembled horizontally.

Injection and Drainage Structure. The injection and drainage were designed to be formed in a vertical structure and the injection port was open at the top. When the injection port was made of small holes, the biocement was concentrated around the hole, resulting in uneven strength in the mold. Applying the injection port at the side of the mold interfered with MICP activity. The ideal diameter of the drainage hole was $500 \mu \mathrm{m}$ or less, considering the average size of the sand particles.

\subsection{Mechanical and Chemical Evaluation of Biocement as an Alternative Concrete}

A compressive strength test and analysis of mineralogical composition were employed to determine the biocement sample's mechanical and chemical properties, respectively.

\subsubsection{Compressive Strength Test}

Since the elastic modulus $\left(\mathrm{N} / \mathrm{m}^{2}\right)$ of concrete can be expressed only as the compressive strength, the biocement is also expressed as compressive strength [42]. The elastic modulus $\left(\mathrm{N} / \mathrm{m}^{2}\right)$ of the biocement sample was analyzed using the compressive strength test (Figure 6a). The biocement samples were depressed by a load of $540 \mathrm{~N}$ ten times (Figure $6 \mathrm{~b}$ ). The elastic modulus (E) of the samples was determined to be $3.8 \times 10^{7} \mathrm{~N} / \mathrm{m}^{2}$ (Figure $6 \mathrm{c}$ ). It was assumed that the difference in strength is about $\pm 30 \%$, depending on the composition of the biocement samples. As a result, biocement sample has showed $40 \%$ strength compared with the average compressive strength value $\left(9.5 \times 10^{7} \mathrm{~N} / \mathrm{m}^{2}\right)$ of conventional concrete showing 6 to $13 \times 10^{7} \mathrm{~N} / \mathrm{m}^{2}$ [43]. Therefore, further optimization of biocement strength may justify biocement as an alternative to conventional concrete for general use. 


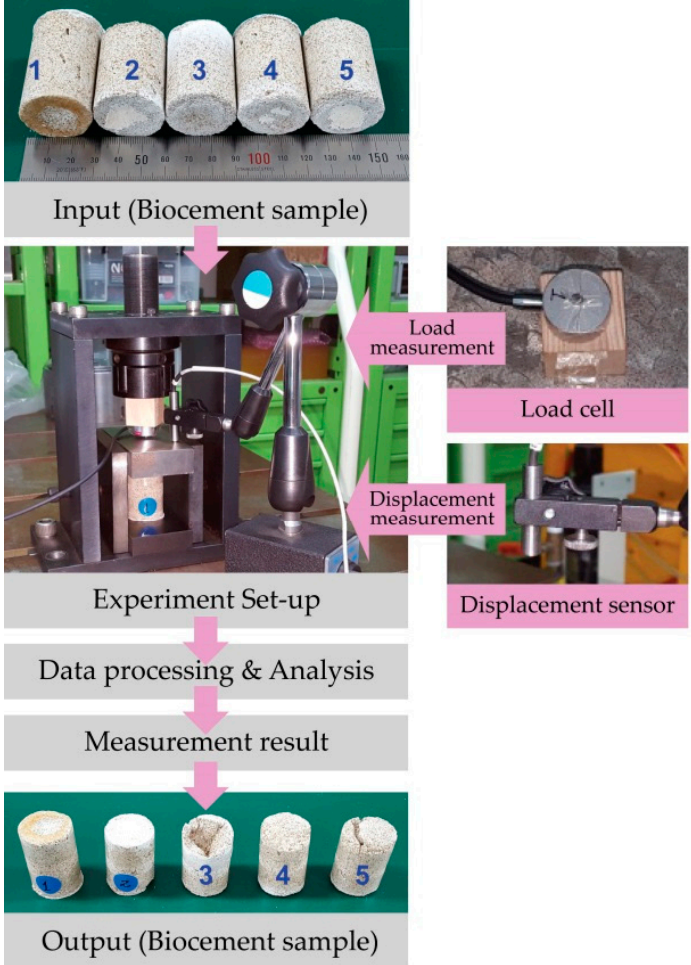

(a)

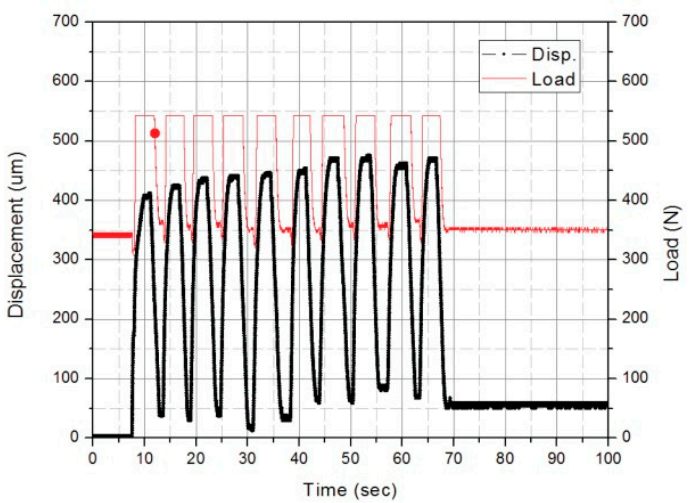

(b)

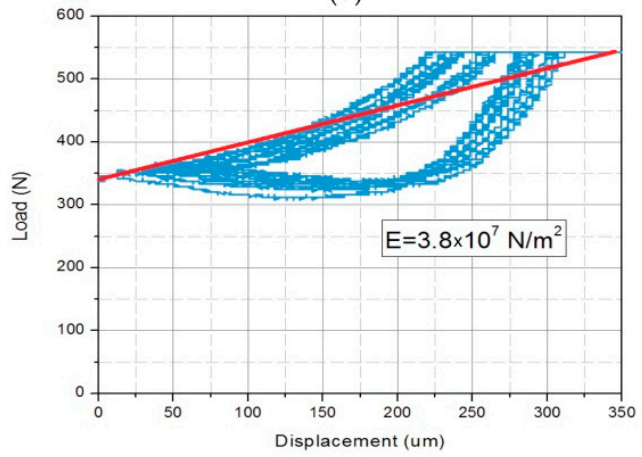

(c)

Figure 6. (a) Experimental setup for the compressive strength test; five samples produced by $1 \mathrm{X}$ bacterial culture and cementation solution $\left(0.75 \mathrm{M} \mathrm{CaCl}_{2}, 1.5 \mathrm{M}\right.$ urea) were prepared for the compressive strength test. The elastic modulus $\left(\mathrm{N} / \mathrm{m}^{2}\right)$ of the biocement sample was measured. (b) Load-displacement measurement. A black line wave indicates that the sample was pushed ten times by the load of $540 \mathrm{~N}$ in the compressive strength and it was endured in the elastic zone. (c) Load-shrinkage diagram. The blue line indicates measured value and the red line indicates average value. The elastic modulus (E) of the sample was measured at $3.8 \times 10^{7}\left(\mathrm{~N} / \mathrm{m}^{2}\right)$.

\subsubsection{XRD (X-ray Diffraction) Analysis}

The biocement sample was cut into three equal parts, then the cross-sectional strength and calcium carbonate composition were visually confirmed. It was found that more $\mathrm{CaCO}_{3}$ was produced at the top part and that higher strength was shown at the top during cutting. On the surface of the bottom part, the combination of calcium carbonate and sand did not form evenly and it was easier to cut than the top (Figure 7a).

Figure $7 \mathrm{~b}$ shows that characteristic peaks of calcium carbonate at $29.4^{\circ}, 35.97^{\circ}, 39.41^{\circ}, 43.17^{\circ}$, and $47.5^{\circ}$ of $2 \theta$ are formed in all three parts of the bio-cement sample. Since the $\mathrm{CaCO}_{3}$ peak was not found in the control sample without bacteria, it was determined that calcium carbonate in the three parts of the biocement sample was precipitated by MICP activity.

In the calcium carbonate peaks (Figure $7 \mathrm{~b}$ ), the calcite, which has the most stable polymorphic structure among the crystal structures of calcium carbonate (calcite, aragonite, and vaterite), was found to be the highest in the calcium carbonate peak. A few peaks of aragonite and vaterite were observed at the bottom of the biocement sample, but this may be attributable to the temperature, which plays an important role in the formation and transformation of the calcium carbonate crystals during the MICP process [44]. Since the calcite enhances bonding between adjacent particles with the hardest bridges, it is believed that high strength is formed in the top and middle of the biocement sample [45]. 


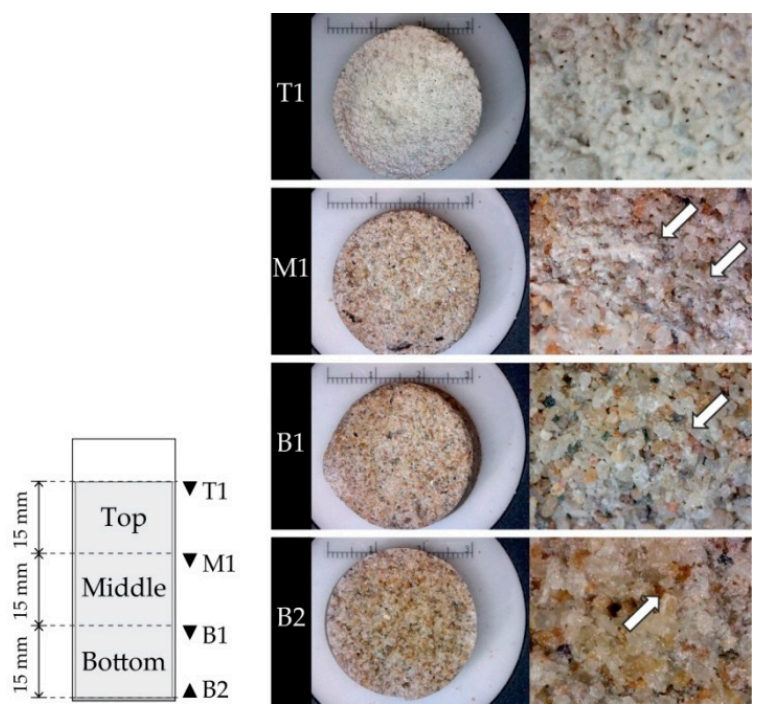

(a)

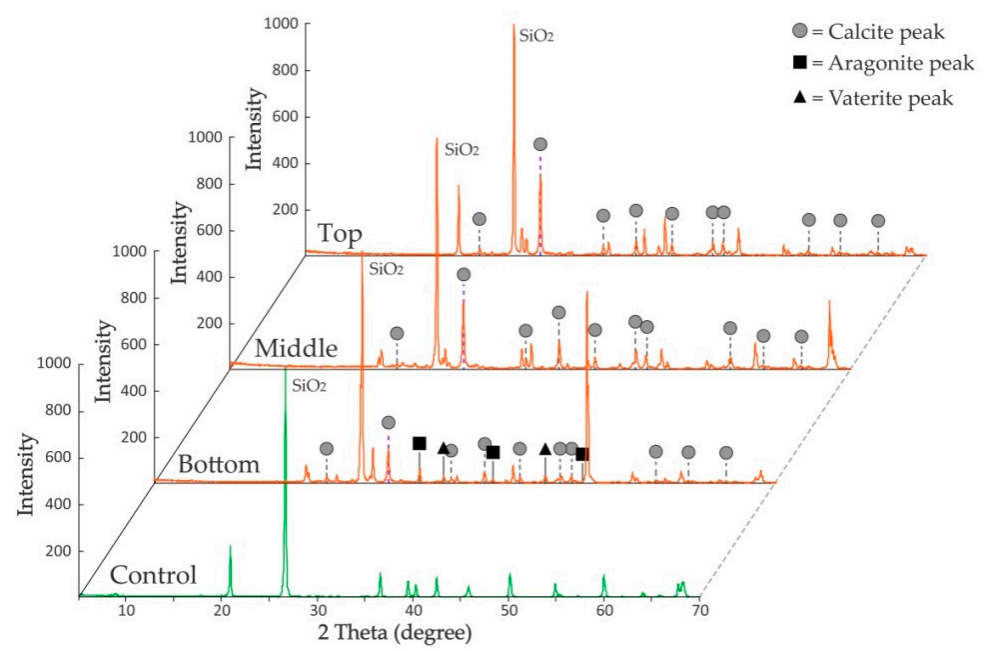

(b)

Figure 7. The result of X-ray diffraction (XRD) shows calcium carbonate composition in the biocement sample: (a) The section of the biocement sample was cut into three equal portions and observed. The top part (T1) has more precipitation of calcium carbonate than the bottom (B2). (b) The mineral composition of the biocement sample was analyzed by XRD in each section of the sample (Top, Middle, Bottom). Control refers to the sand without the bacteria. Circle, calcite; square, aragonite; triangle, vaterite.

\subsection{Compatibility Study of Biocement with Other Minerals and Various Formation Study}

\subsubsection{Compatibility of Biocement}

Results from the compatibility test reveal that the biocement was compatible with the color sand and the waste marble powder, as shown in Figure $8 \mathrm{c}, \mathrm{d}$. The color pattern at the bottom of the sample in Figure 8c showed that the pattern was well formed as initially planned. However, the pattern at the top part was not formed as initially planned due to the water pressure at the time of injection of the cementation solution. In addition, the color of the pattern was faded by precipitation of calcite around the color sand particles. Therefore, it is necessary to consider the color change due to the precipitation of calcium carbonate when applying color to biocement. 


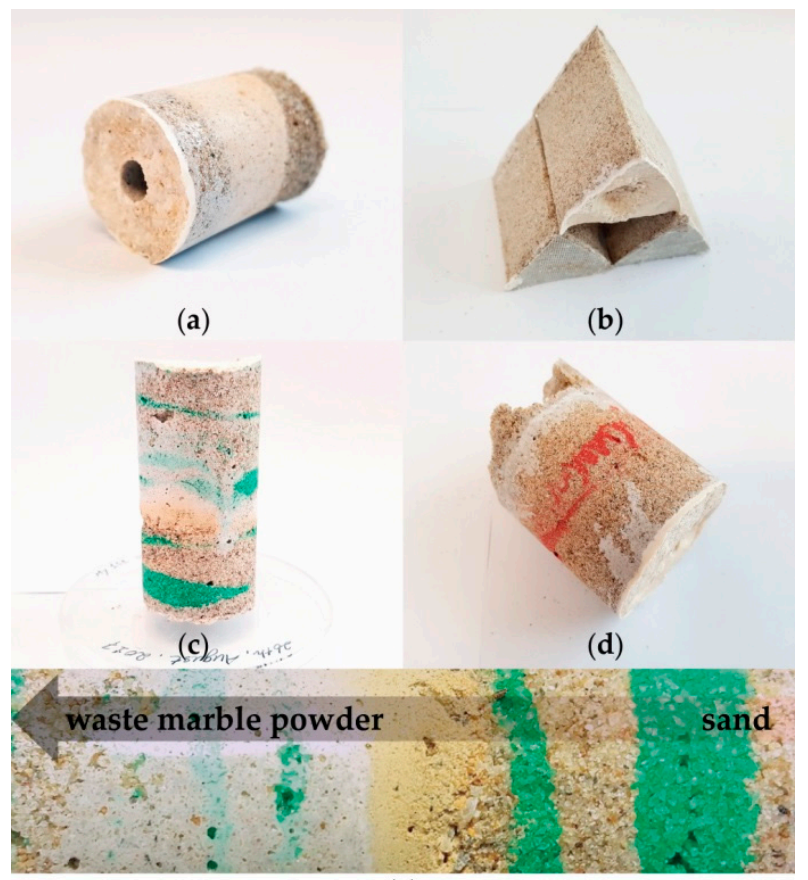

(e)

Figure 8. Different formations using biocement. (a) Cylindrical shape formation using three different sands that make a pattern on the surface. We planned to have a hole in the center of the cylinder. (b) Triangle shape formation using biocement. The metal plates are fixed with the sand by MICP. (c) Biocement sample containing waste marble powder and color sand with $60 \mathrm{~mm}$ height. (d) Biocement sample containing waste marble powder and color sand with $120 \mathrm{~mm}$ height, the part exceeding $60 \mathrm{~mm}$ was easily broken. (e) The surface of biocement containing waste marble powder and color sand.

\subsubsection{Improvement of the Finish Quality of Biocement}

In terms of the improvement of the finish quality, the surface with the waste marble powder had formed a softer finish than the surface with the sand, resulting in high-water impermeability and aesthetic improvement (Figure 8e). It is meaningful that the smooth surface finishes can provide a better experience to the user. The aesthetic aspects such as compatibility with color and the possibility of a smooth finish are important when the biocement is applied to products. Therefore, it is considered that the high compatibility of biocement with color sand and waste marble powder and the improvement of finishing quality by mixing with marble dust increase the possibility of using biocement in areas such as product design.

Figure $8 \mathrm{a}$ shows the bonding of biocement with three different particle sizes of sand, showing a smoother surface texture in the sand with smaller particles. It is also possible to develop various combinations of biocement modules by forming a biocement with a hole in the inside (Figure 8a). Figure $8 \mathrm{~b}$ shows the possibility of bonding between the bio-cement and the iron perforated plate.

However, since PVC moldings are slightly deformed during the biocementation process, uniformity and repeatability should be considered when making various shapes using biocement.

\subsection{Large-Scale Test}

Two samples of different heights (mold A with $60 \mathrm{~mm}$ height, mold B with $120 \mathrm{~mm}$ height) were tested under the same optimized conditions in order to investigate the scalability of the biocement sample. As a result, it was identified that the sample was hardened only below $60 \mathrm{~mm}$. When the height of the sample exceeded $60 \mathrm{~mm}$, the part exceeding $60 \mathrm{~mm}$ was easily broken or formed into a weak structure, as seen in Figure 8d. Further scalability studies are needed to optimize the application of biocement. 


\subsection{Potential of Using Biocement in the Design Application}

Figure 9 shows concept images of the biocement module using biocement that serves as a breeding place for wild bees and as brick for construction. As a design application, the module block to house wild bees can be installed in the garden, which can allow more wild bees to reproduce (Figure 9a). A biocement module can be installed as one block in the brick wall, or as an independent structure built with biocement modules.

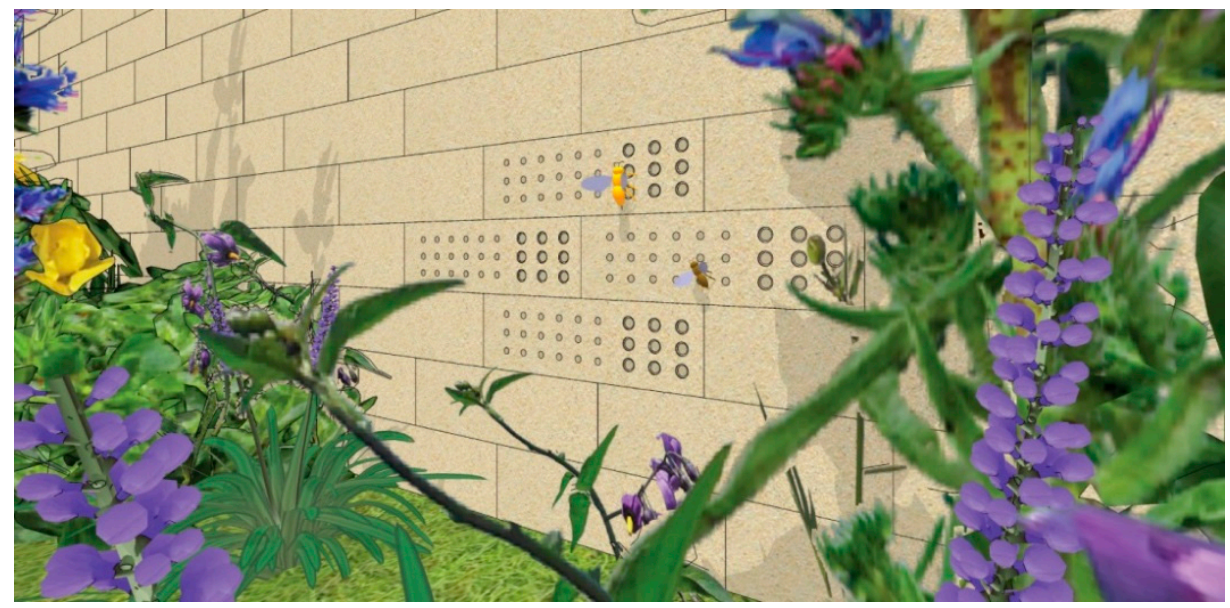

(a)
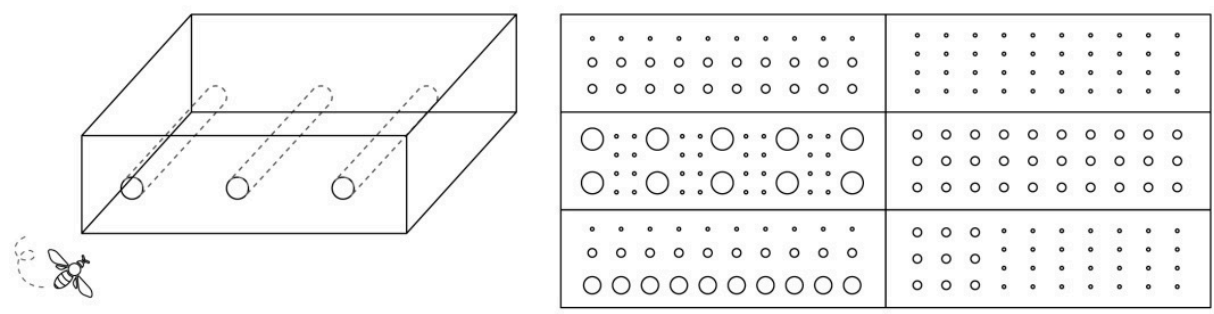

(b)
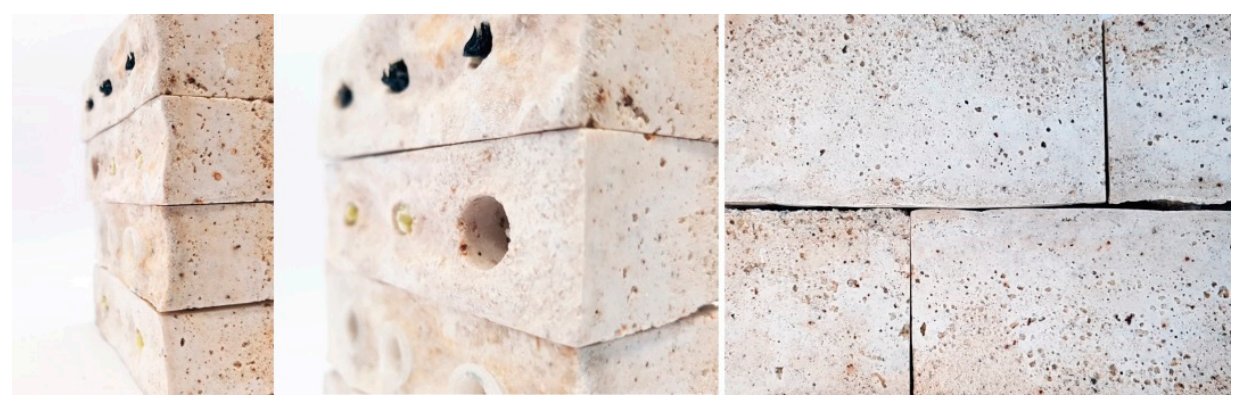

(c)

Figure 9. Biocement application to bee nesting. Biocement was applied in a brick module to serve as a nest of wild bees and as a basic building material for human construction. (a) Bee block module installed in garden. (b) Basic block module and the combination of block modules which have differently-sized holes to accommodate many wild bees. (c) Bee block prototype fabricated with biocement.

In addition, various combinations of hole patterns can be developed, as shown in Figure 9b,c, so that many species of wild bees can reproduce in different holes that match their sizes.

The module size used here was $85 \mathrm{~mm} \times 45 \mathrm{~mm} \times 28 \mathrm{~mm}$ which is half of the conventional brick size due to the height limitation discussed in the above study. Considering the habitats of wild bees, the holes were casted using recycled $2-10 \mathrm{~mm}$ polypropylene straws. The holes in the bricks are blocked on just one side of the habitat of wild bees, and the bees' nest is protected from moisture since the biocement does not allow water to pass through. Unfortunately, the polypropylene straws 
used to template the holes were not removed from the brick due to friction between the straw and the biocement. Thus, the casting material requires other environmentally friendly materials such as wood tubes to be used in place of polypropylene.

To install the bricks on an independent structure without installing them on the walls, the brick modules themselves can be manufactured in a form where they are connected to each other. For this method, we have studied various module types, as seen in Figure 8. For strong integration between the modules, the module requires unity and high strength, both of which are necessary for development. As shown in Figure 8, bricks can be applied with various types of sand on the surface, additionally allowing for an aesthetic that contains a variety of colors and patterns outside the building.

The concept of this design work is to achieve sustainability through interdisciplinary research in ecology, design, and biology using biocement. In addition, raw materials used for brick modules can be easily obtained locally in non-sterilized conditions, and can be recyclable as well, as seen in this study. Thus it can have less of an environmental impact as a sustainable product in consumption and disposal as compared to conventional cement. In terms of industrial applications using biocement, the unity, scalability, and repeatability of the modules need to be further explored, but the fabrication process using biocement can empower users to design a unique module of their choice.

A potential issue in this biocement fabrication processes includes the ammonia produced via urease activity that may harm the health of animals and humans (though the module smells negligibly of ammonia after being dried in an oven).

\section{Conclusions}

In this study, engineering and aesthetic aspects of the MICP process were applied to the design field. Although the compressive strength of our proposed concrete is still lower than that of conventional concrete, its potential as a new environmentally-friendly design material has been observed, showing positive results in terms of water permeability, compatibility with other materials, and material finish. This research contributes foundational research regarding design applications using biomaterials by combining knowledge from biological mechanism research, engineering aspects, and design applications. Future research will focus on improvements in strength and durability, which are necessary for use as a design material.

Supplementary Materials: The following are available online at http:/ /www.mdpi.com/2071-1050/10/11/4079/ s1, Figure S1: Growth curve of S.pasteurii, Figure S2: Urease test.

Author Contributions: C.L. did the initial design, data visualization, and performed all the experiments and design application works. O.B.K supervised the experimental research and supported all the laboratory resources for experiments. H.L. supervised the design research frame. C.L. prepared the manuscript and wrote the paper. O.B.K. reviewed and edited the paper.

Funding: This work was supported by the Basic Science Research Program (NRF-2015R1C1A2A01053608) and Basic Research Laboratory (BRL) (NRF-2015R1A4A1041997) through the National Research Foundation of Korea.

Acknowledgments: The authors acknowledge all the supports from Laboratory of Microbiology \& Biorefinery at Ewha Womans University. Also, Nano Material Laboratory at Ewha Womans University helped to measure X-ray Powder Diffraction (XRD), and Korea Institute of Machinery and Materials (KIMM) supported the compressive strength test.

Conflicts of Interest: The authors declared no conflict of interest.

\section{References}

1. Manzini, E. New design knowledge. Des. Stud. 2009, 30, 4-12. [CrossRef]

2. Ehrenfeld, J. Sustainability by Design: A Subversive Strategy for Transforming Our Consumer Culture; Yale University: New Haven, CT, USA, 2008.

3. Myers, W. Bio Design: Nature, Science, Creativity; Museum of Modern Art: New York, NY, USA, 2012.

4. Camere, S.; Karana, E. Fabricating materials from living organisms: An emerging design practice. J. Clean. Prod. 2018, 186, 570-584. [CrossRef] 
5. Mogas-Soldevila, L.; Duro-Royo, J.; Lizardo, D.; Kayser, M.; Patrick, W.; Sharma, S.; Keating, S.; Klein, J.; Inamura, C.; Oxman, N. Designing the ocean pavilion: Biomaterial templating of structural, manufacturing, and environmental performance. In Proceedings of the International Association for Shell and Spatial Structures, Amsterdam, The Netherland, 20 August 2015; Available online: http:/ /neri.media.mit.edu/ assets / pdf/IASS2015_MediatedMatter_small.pdf (accessed on 30 October 2018).

6. Worrell, E.; Price, L.; Martin, N.; Hendriks, C.; Meida, L.O. Carbon dioxide emissions from the global cement industry. Ann. Rev. Energy Environ. 2001, 26, 303-329. [CrossRef]

7. Benhelal, E.; Zahedi, G.; Shamsaei, E.; Bahadori, A. Global strategies and potentials to curb $\mathrm{CO}_{2}$ emissions in cement industry. J. Clean. Prod. 2013, 51, 142-161. [CrossRef]

8. Ivanov, V.; Chu, J.; Stabnikov, V. Basics of construction microbial biotechnology. In Biotechnologies and Biomimetics for Civil Engineering; Springer: Berlin, Germany, 2015; pp. 21-56.

9. Monks, K. Would you live in a house made of sand and bacteria? It's a surprisingly good idea. CNN, 20 May 2014.

10. De Muynck, W.; De Belie, N.; Verstraete, W. Microbial carbonate precipitation in construction materials: A review. Ecol. Eng. 2010, 36, 118-136. [CrossRef]

11. Dhami, N.K.; Reddy, M.S.; Mukherjee, A. Biomineralization of calcium carbonates and their engineered applications: A review. Front. Microbiol. 2013, 4, 314. [CrossRef] [PubMed]

12. Sarda, D.; Choonia, H.S.; Sarode, D.; Lele, S. Biocalcification by Bacillus pasteurii urease: A novel application. J. Ind. Microbiol. Biotechnol. 2009, 36, 1111-1115. [CrossRef] [PubMed]

13. Hamed Khodadadi, T.; Kavazanjian, E.; Van Paassen, L.; DeJong, J. Bio-grout materials: A review. Geotech. Spec. Publ. 2017, 288, 1-12.

14. Dhami, N.K.; Reddy, M.S.; Mukherjee, A. Improvement in strength properties of ash bricks by bacterial calcite. Ecol. Eng. 2012, 39, 31-35. [CrossRef]

15. Stocks-Fischer, S.; Galinat, J.K.; Bang, S.S. Microbiological precipitation of $\mathrm{CaCO}_{3}$. Soil Biol. Biochem. 1999, 31, 1563-1571. [CrossRef]

16. Anbu, P.; Kang, C.-H.; Shin, Y.-J.; So, J.-S. Formations of calcium carbonate minerals by bacteria and its multiple applications. Springerplus 2016, 5, 250. [CrossRef] [PubMed]

17. Boling, J. Bioprecipitation of Calcite by Sporosarcina pasteurii: Developing Efficient Methodologies for Microbially Indurated Rammed Earth. Ph.D. Thesis, University of Kansas, Lawrence, KS, USA, 2015.

18. Phillips, A.J.; Gerlach, R.; Lauchnor, E.; Mitchell, A.C.; Cunningham, A.B.; Spangler, L. Engineered applications of ureolytic biomineralization: A review. Biofouling 2013, 29, 715-733. [CrossRef] [PubMed]

19. Al-Thawadi, S. High Strength In-Situ Biocementation of Soil by Calcite Precipitating Locally Isolated Ureolytic Bacteria. Ph.D. Thesis, Murdoch University, Perth, Australia, 2008.

20. Fortin, D.; Ferris, F.; Beveridge, T. Surface-mediated mineral development by bacteria. Rev. Mineral. Geochem. 1997, 35, 161-180.

21. Dosier, G.K. Methods for Making Construction Material Using Enzyme Producing Bacteria. Patent 8,728,365, 20 May 2014.

22. Brownell, B.E.; Swackhamer, M.T. Hypernatural: Architecture's New Relationship with Nature; Princeton Architectural Press: New York City, NY, USA, 2015.

23. Hammes, F.; Verstraete, W. Key roles of ph and calcium metabolism in microbial carbonate precipitation. Rev. Environ. Sci. Biotechnol. 2002, 1, 3-7. [CrossRef]

24. Cheng, L.; Shahin, M.A.; Mujah, D. Influence of key environmental conditions on microbially induced cementation for soil stabilization. J. Geotech. Geoenviron. Eng. 2016, 143, 04016083. [CrossRef]

25. Khodadadi Tirkolaei, H.; Bilsel, H. Estimation on ureolysis-based microbially induced calcium carbonate precipitation progress for geotechnical applications. Mar. Georesour. Geotechnol. 2017, 35, 34-41. [CrossRef]

26. González-Varo, J.P.; Biesmeijer, J.C.; Bommarco, R.; Potts, S.G.; Schweiger, O.; Smith, H.G.; Steffan-Dewenter, I.; Szentgyörgyi, H.; Woyciechowski, M.; Vilà, M. Combined effects of global change pressures on animal-mediated pollination. Trends Ecol. Evol. 2013, 28, 524-530. [CrossRef] [PubMed]

27. Baldock, K.C.; Goddard, M.A.; Hicks, D.M.; Kunin, W.E.; Mitschunas, N.; Osgathorpe, L.M.; Potts, S.G.; Robertson, K.M.; Scott, A.V.; Stone, G.N. Where Is the UK's Pollinator Biodiversity? The Importance of Urban Areas for Flower-Visiting Insects. Proc. R. Soc. B 2015, 282, 20142849. [CrossRef] [PubMed]

28. Glaum, P.; Simao, M.-C.; Vaidya, C.; Fitch, G.; Iulinao, B. Big city bombus: Using natural history and land-use history to find significant environmental drivers in bumble-bee declines in urban development. Roy. Soc. Open Sci. 2017, 4, 170156. [CrossRef] [PubMed] 
29. Hernandez, J.L.; Frankie, G.W.; Thorp, R.W. Ecology of urban bees: A review of current knowledge and directions for future study. CATE 2009, 2, 3. [CrossRef]

30. Kellert, S.R.; Heerwagen, J.; Mador, M. Biophilic Design: The Theory, Science and Practice of Bringing Buildings to Life; John Wiley \& Sons: Hoboken, NJ, USA, 2011.

31. Matteson, K.C.; Ascher, J.S.; Langellotto, G.A. Bee richness and abundance in New York City urban gardens. Ann. Entomol. Soc. Am. 2008, 101, 140-150. [CrossRef]

32. Al Qabany, A.; Soga, K. Effect of chemical treatment used in MICP on engineering properties of cemented soils. Géotechnique 2013, 63, 331. [CrossRef]

33. Kim, G.; Youn, H. Microbially induced calcite precipitation employing environmental isolates. Materials 2016, 9, 468. [CrossRef] [PubMed]

34. Ramachandran, S.K.; Ramakrishnan, V.; Bang, S.S. Remediation of concrete using micro-organisms. ACI Mater. J.-Am. Concr. Inst. 2001, 98, 3-9.

35. Chunxiang, Q.; Jianyun, W.; Ruixing, W.; Liang, C. Corrosion protection of cement-based building materials by surface deposition of $\mathrm{CaCO}_{3}$ by Bacillus pasteurii. Mater. Sci. Eng. C 2009, 29, 1273-1280. [CrossRef]

36. Gorospe, C.M.; Han, S.-H.; Kim, S.-G.; Park, J.-Y.; Kang, C.-H.; Jeong, J.-H.; So, J.-S. Effects of different calcium salts on calcium carbonate crystal formation by Sporosarcina pasteurii KCTC 3558. Biotechnol. Bioprocess Eng. 2013, 18, 903-908. [CrossRef]

37. Mobley, H.; Hausinger, R. Microbial ureases: Significance, regulation, and molecular characterization. Microbiol. Rev. 1989, 53, 85-108. [PubMed]

38. Cheng, L.; Cord-Ruwisch, R. Upscaling effects of soil improvement by microbially induced calcite precipitation by surface percolation. Geomicrobiol. J. 2014, 31, 396-406. [CrossRef]

39. DeJong, J.T.; Fritzges, M.B.; Nüsslein, K. Microbially induced cementation to control sand response to undrained shear. J. Geotech. Geoenviron. Eng. 2006, 132, 1381-1392. [CrossRef]

40. Whiffin, V.S. Microbial $\mathrm{CaCO}_{3}$ Precipitation for the Production of Biocement. Ph.D. Thesis, Murdoch University, Perth, Australia, 2004.

41. Kucharski, E.S.; Cord-Ruwisch, R.; Whiffin, V.; Al-thawadi, S.M. Microbial Biocementation. Patent 8,182,604, 22 May 2012.

42. Beer, F.P.; Johnston, E.R.; DeWolf, J.T.; Mazurek, D.F. Mechanics of Materials; McGraw-Hill: New York, NY, USA, 1992.

43. Rashid, M.A.; Mansur, M.A. Considerations in producing high strength concrete. J. Civil Eng. (IEB) 2009, 37, 53-63.

44. Wang, H.; Alfredsson, V.; Tropsch, J.; Ettl, R.; Nylander, T. Formation of $\mathrm{CaCO}_{3}$ deposits on hard surfaces effect of bulk solution conditions and surface properties. ACS Appl. Mater. Interfaces 2013, 5, 4035-4045. [CrossRef] [PubMed]

45. Martinez, B.C.; DeJong, J.T. Bio-mediated soil improvement: Load transfer mechanisms at the micro-and macro-scales. In Proceedings of the U.S.-China Workshop on Ground Improvement Technologies, Orlando, FL, USA, 14 March 2009.

(C) 2018 by the authors. Licensee MDPI, Basel, Switzerland. This article is an open access article distributed under the terms and conditions of the Creative Commons Attribution (CC BY) license (http://creativecommons.org/licenses/by/4.0/). 